\title{
Proteins Profile in Milk from Three Species of Ruminants
}

\author{
Anamaria COZMA ${ }^{1}$, Sanda ANDREI ${ }^{2}$, Doina MIERE ${ }^{1}$, Lorena FILIP', Felicia LOGHIN³ \\ ${ }_{1}^{1}$ "Iuliu Hatieganu" University of Medicine and Pharmacy, Department of Environmental Chemistry and \\ Hygiene, Faculty of Pharmacy, 6 Pasteur Street, Cluj-Napoca, Romania; apcozma@yahoo.com \\ ${ }^{2}$ University of Agronomical Sciences and Veterinary Medicine, Faculty of Veterinary Medicine, Department \\ of Biochemistry and Clinical Laboratory, 3-5 Manastur Street, Cluj-Napoca, Romania \\ 3 "Iuliu Hatieganu" University of Medicine and Pharmacy, Department of Toxicology, Faculty of Pharmacy, 6 Pasteur Street, Cluj-Napoca, Romania
}

\begin{abstract}
Milk proteins, caseins and whey proteins, are very important nutritionally, as they contain all essential aminoacids in optimal proportions and are the most important source of bioactive peptides. These peptides are protein fragments resulting from enzymatic hydrolysis of milk proteins, which carry numerous beneficial effects on the cardiovascular, nervous, gastrointestinal and immune systems. In this research, total proteins, caseins and whey proteins respectively, were dosed in milk from three species of ruminants-cow, goat and sheep, using a very sensitive method, Bradford photometric method. The highest content of total proteins was obtained in sheeps' milk $(65.92 \mathrm{mg} / \mathrm{ml})$ and the lowest in cows' milk $(40.03 \mathrm{mg} / \mathrm{ml})$, intermediate values occurring in goats' milk $(46.79 \mathrm{mg} / \mathrm{ml})$. The lowest amount of caseins was found in cow milk $(28.26 \mathrm{mg} / \mathrm{ml})$, followed by sheep milk $(42.55 \mathrm{mg} / \mathrm{ml})$ and goat milk $(44.03 \mathrm{mg} / \mathrm{ml})$. When the case of whey proteins, the highest values occur in sheep milk $(23.36 \mathrm{mg} / \mathrm{ml})$ and the lowest in cow milk $(11.79 \mathrm{mg} / \mathrm{ml})$, goat milk having intermediate values $(17.7 \mathrm{mg} / \mathrm{ml})$. The results obtained indicate the dependence of protein concentration in milk of the studied ruminant species and stresses the importance of including goat and sheep milk in daily diet, along with cow milk, for an optimal intake of protein.
\end{abstract}

Keywords: Bradford method, milk, proteins, ruminants

\section{Introduction}

Over the past two decades the importance of proteins in human diet has increased significantly as a result of numerous researches in the field of nutrition. In terms of nutrition, milk proteins are very important as they contain all the essential aminoacids in the right proportions. A daily consumption of 0.5 litres of milk is enough to satisfy the quantity of aminoacids the body needs during 24 hours, except for the methionine (Tibulca and Jimborean, 2008).

The two major categories of milk proteins are: insoluble proteins (the casein family) and soluble proteins (whey proteins), found in lactoserum. The casein family of proteins consists of several types of caseins: $\alpha$ s1-, $\alpha s 2-$, $\beta$-, K- and $\gamma$-, while the whey proteins are $\alpha$-lactalbumin and $\beta$-lactoglobulin. Milk also comprises important minor proteins, such as serum albumin, immunoglobulins, lactoferrin, transferrin, calcium-binding protein, prolactin, folate-binding protein and protease-peptone (Park et al., 2007).

Recent studies have shown that milk proteins are the most important source of bioactive peptides. They are fragments of proteins formed under the action of digestive enzymes when passing through the gastrointestinal tract or resulted during food processing, by fermentation and maturation (Korhonen, 2009; Steijns, 2001).
Therefore, bioactive peptides from milk proteins are fragments resulted from the enzymatic hydrolysis of milk proteins which, dependently of the aminoacids and their sequence, exert a specific biological activity over different organs' activities in human body:

- the cardiovascular system: anti-hypertensive activity, anti-thrombotic activity, hipocholesterolemiant activity, antioxidant activity (Fitzgerald et al., 2004; Korhonen and Pihlanto, 2006; Pihlanto, 2006; Silva and Malcata, 2005);

- the nervous system: agonist opioid activity, antagonist opioid activity (Korhonen and Pihlanto, 2006; Silva and Malcata, 2005);

- the gastrointestinal system: regulation of mineral absorption, anorexigen activity (Clare and Swaisgood, 2000; Korhonen and Pihlanto, 2006);

- the immune system: antimicrobian activity, immunomodulating activity, cytomodulating activity (Korhonen and Pihlanto, 2006; Park et al., 2007).

The quantity of proteins in milk differs from one species to another, which influences the uptake of essential amino acids and bioactive peptides, depending on the type of milk consumed. Taking into consideration that in our country one consumes mainly cow milk, followed by goat milk and sheep milk, the purpose of this paper is to analyse the quantity of proteins contained by the three above mentioned types of milk. 
In recent years, the methods performed to analyze milk proteins were electrophoresis techniques using polyacrylamide gels with urea (UREA-PAGE) or sodium dodecylsulphate (SDS-PAGE) and isoelectric focusing (IEF), high performance liquid chromatography (HPLC) in different systems like ion-exchange, hydrophobic interaction and reversed phase, immunological methods, UV-VIS spectrophotometry and mass spectrometry (Andrei, 2006).

For this assay, the Bradford photometric method has been used to determine the protein concentrations in milk, based on the Blue Coomassie biological stain that changes colour from brown into blue, by absorption on the proteins surface, in an acid environment. It is a very sensitive $(2-5 \mu \mathrm{g})$ and extremely rapid method. The method is also particularly resistant to contaminant agents, solely the detergents (Triton and sodium dodecyl sulfate) may interfere (Bradford, 1976).

The researches results enable to choose that particular type of milk that brings an optimum uptake of proteins, both in the diet of healthy and ill persons.

\section{Materials and methods}

The quantity of milk proteins, caseins and whey proteins, was determined in several phases. During the first phase, the quantity of milk total proteins was determined using the Bradford photometric method. During the next phase, the caseins were precipitated $(\mathrm{pH}=4,6)$, the lactoserum was separated by filtration and its proteins were dosed. The difference between the total proteins and the whey proteins was used to obtain the concentration in caseins of milk samples. All these assessments were established on milk samples previously degreased (Pintea et al., 2008).

Milk degreasing: samples of $20 \mathrm{ml}$ of milk were centrifuged at 5000 RPM, for 20 minutes, and then kept for 30 minutes at $4^{\circ} \mathrm{C}$. The upper phase, which is the fat substance was removed using a spatula, and the lower aqueous phase, the degreased milk, was transferred to another tubing.

Preparation of Bradford reactive: in a measuring bottle of $1000 \mathrm{ml}, 100 \mathrm{mg}$ of Blue Coomassie were weighted and dissolved in $50 \mathrm{ml}$ of $95 \%$ ethylic alcohol. $100 \mathrm{ml}$ of $85 \%$ phosphoric acid was added and completed with distilled water. This reaction mixture was filtered through Whatman filter paper.

Determining the etalon curve: dosing the proteins with the Bradford method implied getting the etalon curve by using protein solutions of exactly known concentration, and a stock solution of bovine serum albumin (BSA) of $1 \mathrm{mg} / \mathrm{ml}$ concentration.

The dosage of the total proteins of milk: the first step of this process is the dissociation of casein micelles and the solubilisation of proteins, process also known as the clarification of milk. This was realised using a clarification solution of urea and dithiothrietol (DTT). At $20 \mu$ lof degreased milk a quantity of $140 \mu \mathrm{l}$ clarification reactive was added (dilution 1:8) and then shaken.
For the dosing stage, $20 \mu \mathrm{l}$ of clarified milk and $480 \mu \mathrm{l}$ of distilled water were measured and $500 \mu \mathrm{l}$ of Bradford reactive were added. The samples were well mixed and left still for 5 minutes. $1 \mathrm{ml}$ of distilled water was added then to the samples and their absorbance was determined using an AbleJasco spectrophotometer, at the wavelength of 595 $\mathrm{nm}\left(\lambda_{\max }\right)$.

The precipitation of caseins and the dosing of whey proteins: in the first step, the $\mathrm{pH}$ of the degreased milk was determined using a portable $\mathrm{pH}$ meter. During the second step, the precipitation of caseins was done by treating $5 \mathrm{ml}$ of degreased milk with $\mathrm{HCl} 1 \mathrm{M}$ up to $\mathrm{pH}=4,6$, and then the samples were centrifuged for 20 minutes, at $5000 \mathrm{rpm}$. One may observe the deposition of a casein precipitate, the upper aqueous phase being the lactoserum.

The dosing of the whey proteins was carried on by the photometric method above mentioned: to $40 \mu \mathrm{l}$ of lactoserum and $460 \mu \mathrm{l}$ of distilled water were measured, were added $500 \mu \mathrm{l}$ of Bradford reactive. The samples were well mixed and left still for 5 minutes. $1 \mathrm{ml}$ of distilled water was added then to the samples and their absorbance was determined using the spectrophotometer at the wavelength of $595 \mathrm{~nm}\left(\lambda_{\max }\right)$.

\section{Results and discussion}

The proteins concentration of the milk samples evaluated was calculated based on the etalon curve equation (Fig. 1).

Tab. 1 displays the results obtained when dosing the total proteins, caseins and whey proteins of degreased milk obtained from the three species-cow, goat and sheep. Three samples of milk were analysed for each species and afterwards the arithmetic mean of the three assessments was calculated.

The results obtained prove the dependence of protein concentration in milk types of the ruminant species (Fig. 2).

The highest concentration in total proteins appears in the case of sheep milk $(65.92 \mathrm{mg} / \mathrm{ml})$, respectively the

Tab. 1 . The concentration $(\mathrm{mg} / \mathrm{ml}$ milk) of total proteins, caseins, whey proteins in degreased milk of cow, goat and sheep

\begin{tabular}{cccc}
\hline Sample & $\begin{array}{c}\text { Total proteins } \\
(\mathrm{mg} / \mathrm{ml})\end{array}$ & $\begin{array}{c}\text { Caseins } \\
(\mathrm{mg} / \mathrm{ml})\end{array}$ & $\begin{array}{c}\text { Lactoserum } \\
\text { proteins }(\mathrm{mg} / \mathrm{ml})\end{array}$ \\
\hline Cow milk & 28.90 & 19.76 & 9.21 \\
& 36.50 & 24.25 & 12.25 \\
\hline Mean-cow milk & 54.71 & 40.79 & 13.92 \\
\hline Goat milk & 40.03 & 28.26 & 11.79 \\
\hline Mean-goat milk & 59.50 & 41.19 & 18.31 \\
\hline Sheep milk & 17.01 & - & 17.82 \\
& 63.87 & 46.88 & 16.99 \\
\hline & 68.10 & 449.03 & 17.7 \\
\hline Mean-sheep milk & 60.73 & 35.11 & 27.85 \\
\hline
\end{tabular}




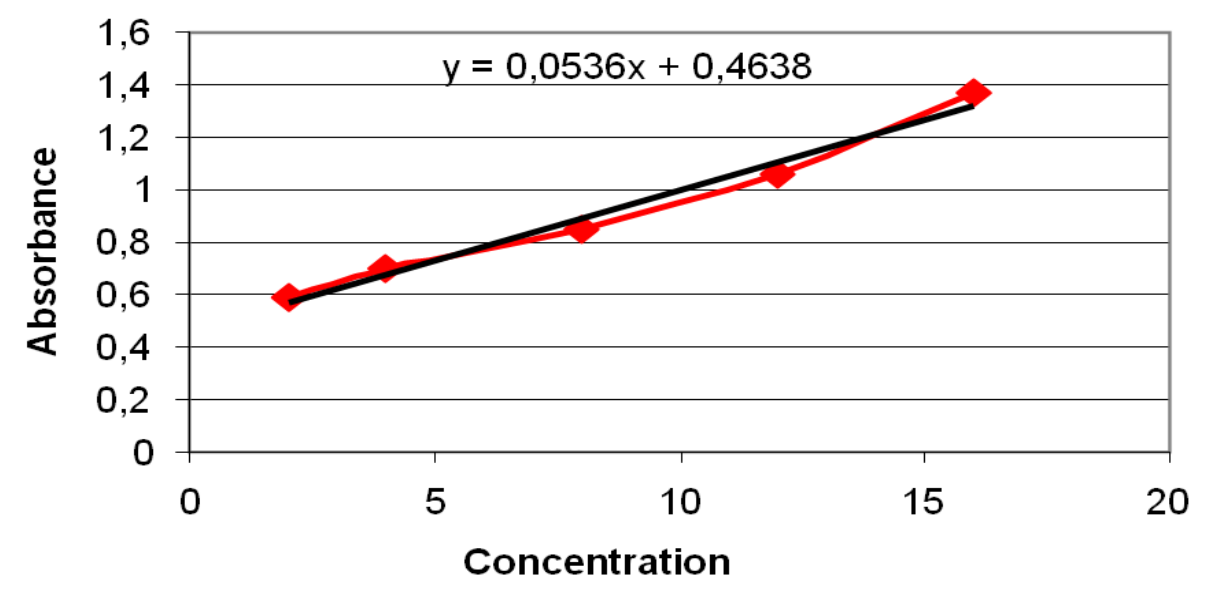

Fig. 1. The etalon curve obtained using the BSA standard solution

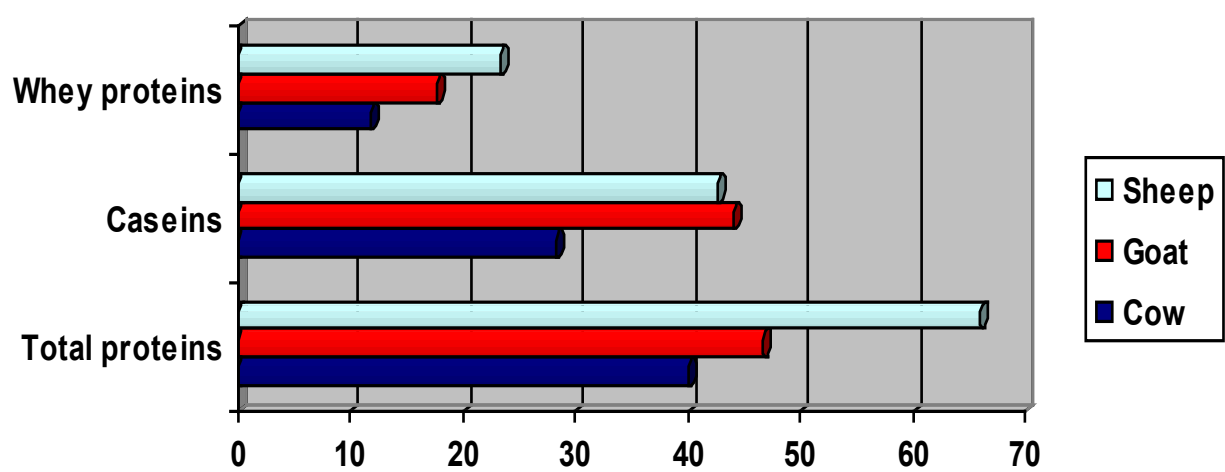

Fig. 2 The profile of proteins in cow, goat and sheep milk

lowest in the case of cow milk $(40.03 \mathrm{mg} / \mathrm{ml})$, while intermediary values are recorded in the case of goat milk (46,.9 $\mathrm{mg} / \mathrm{ml}$ ).

The lowest content of caseins appears in cow milk $(28.26 \mathrm{mg} / \mathrm{ml})$, while the highest content appears in goat milk $(44.03 \mathrm{mg} / \mathrm{ml})$. The content of caseins displays resembling values in case of goat milk and sheep milk (over $40 \mathrm{mg} / \mathrm{ml}$ milk).

The highest values of whey proteins appear in sheep milk $(23.36 \mathrm{mg} / \mathrm{ml})$ and the lowest in cow milk (11.79 $\mathrm{mg} / \mathrm{ml})$.

\section{Conclusions}

Bradford method is a photometric method characterised by high sensitivity, which allows establishing the concentration of milk proteins. The results obtained by applying this method point out a dependence between the milk content in total proteins, respectively protein fractions (caseins, whey proteins) and the ruminant species obtained from.

The highest quantity of total proteins is present in the case of sheep milk, while the lowest in the case of cow milk. The lowest content of caseins is with cow milk, while the highest is in goat milk. In fact, the concentration in caseins of goat milk is similar to the concentration of these phosphoproteins in sheep milk. As for the whey proteins, the highest values are shown in sheep milk and the lowest in cow milk.

The pieces of information provided by this research point out the importance of including goat and sheep milk in daily diet, along with cow milk, for an optimal intake of protein. 


\section{References}

Andrei S (2006). Analytical methods used for milk proteins separation and identification. Bulletin of University of Agricultural Sciences and Veterinary Medicine Cluj-Napoca, series Veterinary Medicine 63:16-21.

Bradford M (1976). A rapid and sensitive method for the quantitation of microgram quantities of protein utilizing the principle of protein-dye binding. Anal Biochem 72:248254.

Clare D, Swaisgood H (2000). Bioactive milk peptides: a prospectus. J Dairy Sci 83:1187-1195.

Fitzgerald RJ, Murray BA, Walsh DJ (2004). Hypotensive peptides from milk proteins. J Nutr 134:980-988.

Korhonen H (2009). Milk-derived bioactive peptides: From science to applications. J Funct Foods 1:177-187.

Korhonen H, Pihlanto A (2006). Bioactive peptides: Production and functionality. Int Dairy J 16:945-960.
29

Park YW, Juarez M, Ramos M, Haenlein GFW (2007). Physicochemical characteristics of goat and sheep milk. Small Rum Res 68:88-113.

Pihlanto A (2006). Antioxidative peptides derived from milk proteins. Int Dairy J 16:1306-1314.

Pintea A, Andrei S, Bele C (2008). Medical-veterinary biochemistry-practical works. AcademicPres Publishing House, Cluj-Napoca (in Romanian).

Silva S, Malcata FX (2005). Caseins as source of bioactive peptides. Int Dairy J 15:1-15.

Steijns JM (2001). Milk ingredients as nutraceuticals. Int J Dairy Technol 54(3):81-88.

Tibulca D, Jimborean MA (2008). Technology of dairy products. Risoprint Publishing House, Cluj-Napoca (in Romanian). 